\title{
PERBEDAAN KECEMASAN SISWA UJIAN NASIONAL DENGAN TERAPI RELAKSASI OTOT PROGRESIF DI SMK ISLAM SUDIRMAN
}

\author{
Liyanovitasari $^{1}$, Puji Lestari ${ }^{2}$, Zumrotul Choiriyyah ${ }^{3}$ \\ ${ }^{1,2,3}$ Fakultas Keperawatan Universitas Ngudi Waluyo \\ Email: liyanovie05@gmail.com
}

\begin{abstract}
ABSTRAK
Tuntutan kelulusan pada siswa Ujian Nasional mengakibatkan kecemasan. Kecemasan ditandai sulit tidur dan konsentrasi belajar menurun. Kecemasan tersebut dapat diatasi melalui terapi relaksasi otot progresif, dengan menegangkan dan melemaskan otot-otot bagian tubuh. Tujuan penelitian ini adalah untuk menganalisis perbedaan kecemasan siswa Ujian Nasional dengan terapi relaksasi otot progresif. Desain penelitian ini adalah Quasy experimental pre post test one group design. Sampel 40 responden dengan teknik purposive sampling. Instrumen penelitian ini meliputi data demografi, Hamilton anxiety rating scale 14 pertanyaan kecemasan. Responden diberikan terapi relaksasi otot progresif selama 1 minggu dalam 3 sesi, dimana terdapat 3 kali pertemuan dengan jeda waktu 1 hari disetiap pertemuannya. Analisis data menggunakan uji t-test. Hasil penelitian menunjukkan sebelum diberikan terapi relaksasi otot progresif rata-rata kecemasan siswa 29,95, dan sesudah diberikan terapi menjadi 18,20. Hasil akhir menunjukkan terdapat perbedaan nilai kecemasan siswa Ujian Nasional sebelum dan sesudah diberikan terapi relaksasi otot progresif dengan nilai $p$-value $=0,000$. Kesimpulannya adalah adanya perbedaan kecemasan siswa sebelum dan sesudah terapi relaksasi otot progresif di SMK Islam Sudirman Ungaran. Siswa yang mengalami kecemasan saat Ujian Nasional diharapkan menerapkan terapi relaksasi otot progresif agar dapat meningkatkan konsentrasi dalam belajarnya.
\end{abstract}

\section{Kata Kunci : Kecemasan; Terapi Relaksasi Otot Progresif}

\begin{abstract}
Graduation demands on National Exam students result in anxiety. Anxiety is characterized by difficulty sleeping and decreased learning concentration. Such anxiety can be overcome through progressive muscle relaxation therapy, with tense and relaxed muscles of the body. The purpose of this study was to analyze the anxiety differences of National Exam students with progressive muscle relaxation therapy. The design of this research is Quasy experimental pre post test one group design. Sample 40 respondents with purposive sampling technique. The instrument of this study includes demographic data, Hamilton anxiety rating scale 14 anxiety questions. Respondents were given progressive muscle relaxation therapy for 1 week in 3 sessions, where there were 3 meetings with lag time of 1 day in each meeting. Data analysis using t-test. The results showed that before progressive muscle relaxation therapy was given the students' anxiety level was 29,95, and after therapy was 18,20 . The final result shows that there is difference of anxiety value of National Examination students before and after progressive muscle relaxation therapy with $\mathrm{p}$-value $=0,000$. The conclusion is the difference of students' anxiety before and after progressive muscle relaxation therapy at SMK Islam Sudirman Ungaran. Students who experience anxiety when the National Exam is expected to apply progressive muscle relaxation therapy in order to improve concentration in learning.
\end{abstract}

Keywords: Anxiety; Progressive muscle relaxation therapy

Jurnal SMART Keperawatan Sekolah Tinggi Ilmu Kesehatan (STIKes) Karya Husada

Semarang www.stikesyahoedsmg.ac.id/ojs/index.php/sjkp(perawat) 


\section{Pendahuluan}

Ujian Nasional merupakan salah satu fase yang dialami oleh tiap siswa dalam menjalani pendidikan di Indonesia. Pendidikan adalah penentu perkembangan kemajuan suatu bangsa dimana melalui pendidikan dapat dicetak sumber daya yang berkompeten dan berkualitas. Keberhasilan pendidikan dapat dilihat dari keberhasilan pembelajaran yang selama ini dilakukan guru terhadap para siswanya. Untuk menilai dan mengukur pembelajaran yang dilakukan guru terhadap para siswanya diperlukan evaluasi. Evaluasi itu dilakukan untuk menilai dan mengukur seberapa keberhasilan siswanya dalam mengikuti pembelajaran. Evaluasi tersebut dapat dilihat melalui ujian nasional yang biasanya dilaksanakan pada tingkat akhir pendidikan (Wahyudin, 2011).

Setiap tahunnya, standar kelulusan UN yang ditetapkan oleh pemerintah semakin tinggi. Selain rata-rata kelulusan semakin besar juga jumlah mata pelajaran yang diujikan semakin bertambah. Tahun 2010, kriteria kelulusan UN bagi peserta didik adalah pencapaian rata-rata nilai minimal 5,50 untuk seluruh mata pelajaran yang diujikan. Dari rata-rata tersebut nilai minimal 4,00 diperbolehkan untuk paling banyak dua mata pelajaran dan minimal 4,25 untuk mata pelajaran lainnya. Tahun 2011 ini siswa yang tidak lulus tidak memiliki kesempatan lagi untuk mengulang dikarenakan UN ulang ditiadakan. Tuntutan kelulusan yang semakin sukar ini bisa memicu munculnya kecemasan pada siswa dalam menghadapi UN.

Kecemasan adalah kekhawatiran yang tidak jelas dan menyebar, berkaitan dengan perasaan tidak pasti dan tidak berdaya (Stuart \& Laraia, 2013). kecemasan terjadi ketika seseorang mengalami kesulitan menghadapi situasi, masalah, dan tujuan hidup (Videbeck, 2010). Pada kecemasan yang tingkatnya tinggi akan mengakibatkan stres. Kecemasan yang terjadi pada siswa yang akan menghadapi Ujian Nasional adalah normal. Namun, tiap siswa belum tentu dapat mengatasi rasa cemasnya. Hal itu tergantung pada kemampuan siswa tersebut dalam merespon kecemasan yang dialaminya. Hal yang biasa dilakukan untuk mengurangi rasa cemas seperti belajar bersama teman, ikut bimbingan les, memperbanyak ibadah. 
Kecemasan yang berlebihan dalam menghadapi UN akan mengacaukan emosi, mengganggu siklus tidur, menurunkan nafsu makan dan menurunkan kebugaran tubuh. Hal tersebut bila terjadi dapat mengganggu konsentrasi dalam belajar, sakit secara fisik atau menimbulkan problem dalam berinteraksi-sosial. Bahkan jika kecemasan dan stres terus meningkat bisa menjadi depresi dan hal ini diperparah oleh tekanan orang tua yang panik (Hawari, 2012).

Hasil wawancara terhadap siswa di SMK Islam Sudirman Ungaran menyatakan bahwa mendekati UN siswa merasakan kecemasan yang berlebih dengan disertai ketegangan fisiologis yaitu merasa khawatir, gemetaran, berkeringat dingin, semakin sering ke kamar mandi, dan merasa berdebar-debar. Wawancara juga dilakukan pada guru wali kelas yang menyatakan bahwa siswa terlihat tidak tenang dan tidak fokus saat proses pembelajaran di kelas ketika semakin mendekati hari UN. Dari hasil observasi peneliti menyatakan bahwa siswa terlihat mengalihkan rasa cemasnya dengan melakukan aktivitas positif belajar kelompok, mengunjungi perpustakaan, mengunjungi laboratorium komputer, dan banyak beribadah. Berdasarkan uraian diatas, maka pemberian terapi relaksasi otot progresif ini diajukan untuk menurunkan kecemasan siswa dalam menghadapi Ujian Nasional.

Adapun salah satu upaya untuk menurunkan kecemasan tersebut, salah satunya dengan pemberian terapi relaksasi otot progresif. Terapi relaksasi otot progresif merupakan suatu terapi yang bertujuan untuk memberikan sensasi ketegangan dan merileksasikan otot-otot tubuh tertentu. Terapi ini dengan cara mengencangkan dan melemaskan otot-otot pada satu bagian tubuh pada satu waktu tertentu untuk memberikan perasaan relaksasi secara fisik. Terapi relaksasi otot progresif merangsang pengeluaran zat-zat kimia endorpin dan enkafalin serta merangsang signal otak yang menyebabkan otot rileks dan meningkatkan aliran darah ke otak (Prawitasari, 2012).

\section{Tinjauan Teoritis}

\section{Kecemasan}

Kecemasan merupakan pengalaman individu yang bersifat subyektif yang sering bermanifestasi sebagai perilaku yang disfungsional yang diartikan sebagai perasaan kesulitan dan kesusahan 
terhadap kejadian yang tidak diketahui dengan pasti (Videbeck, 2010). Kecemasan dapat disebabkan adanya faktor predisposisi seperti biologi, psikologis, serta sosial budaya.Menurut Stuart \& Laraia (2013), kecemasan dibagi menjadi empat diantaranya:

a. Kecemasan ringan, berhubungan dengan ketegangan sehari-hari

b. Kecemasan sedang, memungkinkan individu berfokus pada hal yang penting dan mempersempit lapang persepsi

c. Kecemasan berat, ditandai lapang pandang. Individu cenderung fokus pada sesuatu yang rinci dan spesifik

d. Panik, mencakup disorganisasi kepribadian dan dapat mengancam kehidupan.

Menurut Stuart\&Laraia (2013), tindakan untuk mengatasi kecemasan meliputi:

a. Mekanisme koping

Mekanisme koping terdiri dari dua yakni a). Reaksi yang berorientasi pada tugas, dimana upaya yang disadari dan berorientasi pada tindakan untuk memenuhi tuntutan situasi stres secara realistik; b). Mekanisme pertahanan ego, berlangsung secara relatif pada tingkat tidak sadar dan distorsi realitas.

b. Penanganan medis

Obat antiansietas terdiri dari ansiolitik, transquilizer minor, sedatif. Mekanisme kerja obat ini adalah mendepresi susunan saraf pusat.

c. Tindakan keperawatan

Mencakup terapi kognitif, terapi perilaku, modeling, flooding, serta pencegahan respon.

\section{Konsep Terapi relaksasi otot progresif}

Progressive muscle relaxation (PMR) adalah terapi relaksasi dengan gerakan mengencangkan dan melemaskan otot - otot pada satu bagian tubuh pada satu waktu untuk memberikan perasaan relaksasi secara fisik. Gerakan mengencangkan dan melemaskan secara progresif kelompok otot ini dilakukan secara berturut-turut (Synder \& Lindquist, 2010). Langkah tindakan PMR mencakup: a) Melepaskan kaca mata dan jam tangan, melonggarkan dasi, ikat pinggang, dan pakaian yang ketat, b) Duduk dengan tenang pada posisi nyaman atau berbaring di tempat tidur pada posisi yang nyaman, c) Pastikan lingkungan sekitar tenang, d) Biarkan mata terbuka selama 
beberapa menit. Kemudian secara perlahan menutup mata dan mempertahankannya tetap tertutup, e) Tarik napas dalam beberapa kali sebelum memulai latihan. Hirup napas dalam secara perlahan-lahan melalui hidung dan hembuskan keluar melalui mulut, f) Menggenggam tangan kiri sambil membuat suatu kepalan dan merasakan sensasi ketegangan yang terjadi, dipandu untuk merasakan rileks selama 10 detik. Gerakan serupa juga dilakukan pada tangan kanan, h) Menekuk kedua lengan ke belakang pada pergelangan tangan sehingga otot-otot ditangan bagian belakang dan lengan bawah menegang ke langit-langit, i) Melatih otot biceps, dengan menggenggam kedua tangan sehingga menjadi kepalan kemudian membawa kedua kepalan ke pundak sehingga otot otot biceps akan menjadi tegang, j) Melatih otot bahu, mengangkat kedua bahu setinggi tingginya seakan-akan bahu akan dibawa hingga menyentuh kedua telinga, k) Melemaskan otot wajah, mengerutkan dahi dan alis sampai otot-ototnya terasa dan kulitnya keriput, 1) Menutup keras-keras mata sehingga dapat dirasakan ketegangan di sekitar mata dan otot-otot yang mengendalikan gerakan mata.

m) Moncongkan sekuat-kuatnya bagian bibir sehingga akan dirasakan ketegangan di sekitar mulut, n) Mengatupkan rahang diikuti dengan menggiogit gigi-gigi, o) Membawa kepala ke muka, kemudian klien diminta untuk membenamkan dagu ke dadanya sehingga dapat merasakan ketegangan di daerah leher bagian muka, p) Melatih otot punggung, mengangkat tubuh dari sandaran kursi, kemudian punggung dilengkungkan lalu busungkan dada, q) Melemaskan otot dada, klien diminta untuk menarik nafas panjang untuk mengisi paru-paru dengan udara sebanyak-banyaknya kemudian menghembuskan secara perlahan-lahan, r) Melemaskan otot kaki dan paha, meluruskan kedua belah telapak kaki sehingga otot paha terasa tegang. Gerakan ini dengan mengunci lutut sedemikian sehingga ketegangan pindah ke otot-otot betis.

\section{Metode Penelitian}

Penelitian ini dilakukan di SMK Islam Sudirman Ungaran pada tanggal 16-22 Februari 2018. Desain penelitian ini menggunakan metode Quasy experimental pre post test one group design. Teknik pengambilan sampel dengan purposive sampling. Sampel yang digunakan adalah siswa kelas 3 SMK, siswa yang mengalami kecemasan sedang dan berat, bersedia menjadi responden dan kooperatif dengan jumlah 40 responden. Instrumen yang digunakan adalah instrumen data 
demografi, Hamilton anxiety rating scale (HARS) dari 14 item pertanyaan untuk mengukur kecemasan. Variabel independent berupa kecemasan dan variabel dependent adalah terapi relaksasi otot progresif. Teknik penelitian ini adalah responden diberikan terapi relaksasi otot progresif selama 1 minggu dalam 3 sesi, dimana terdapat 3 kali pertemuan dengan jeda waktu 1 hari disetiap pertemuannya. Sebelum diberikan terapi, terlebih dahulu respon dilakukan pre test untuk mengetahui tingkat kecemasannya. Kemudian diberikan terapi mencakup : identifikasi ketegangan otot-otot tertentu yang dirasakan, pelaksanaan terapi relaksasi otot progresif, dan evaluasi kemampuan klien dalam melakukan terapi relaksasi otot progresif. Masing-masing sesi terapi dengan durasi waktu 50 menit. Analisis dalam penelitian ini adalah univariat dan bivariat menggunakan uji t-test.

\section{Hasil Penelitian}

Tabel 1 Hasil analisis karakteristik siswa berdasarkan jenis kelamin

\begin{tabular}{|l|c|c|}
\hline \multicolumn{1}{|c|}{ Jenis Kelamin } & Frekuensi & Persentase (\%) \\
\hline Laki-laki & 33 & 82,5 \\
\hline Perempuan & 7 & 17,5 \\
\hline Jumlah & $\mathbf{4 0}$ & $\mathbf{1 0 0}$ \\
\hline
\end{tabular}

Berdasarkan tabel 1 dapat diketahui bahwa sebagian besar jenis kelamin siswa adalah laki-laki sejumlah $33(82,5 \%)$

Tabel 2 Hasil analisis karakteristik usia siswa dan Kecemasan sebelum dan sesudah

\begin{tabular}{|l|c|c|c|c|c|}
\hline \multicolumn{1}{|c|}{ Variabel } & N & Mean & SD & Min-Maks & 95\% CI \\
\hline Usia siswa & 40 & 17,82 & 0,712 & $17-19$ & $17,60-18,05$ \\
\hline Pre Kecemasan & 40 & 29,95 & 11,188 & $7-56$ & $26,37-33,53$ \\
\hline Post Kecemasan & 40 & 18,20 & 9,121 & $4-51$ & $15,28-21,12$ \\
& & & & & \\
\hline
\end{tabular}


Berdasarkan tabel 2 didapatkan hasil bahwa rata-rata usia siswa adalah 17,28 tahun dengan usia minimum 17 dan maksimum nya 19 tahun. Adapun rata-rata kecemasan siswa sebelum diberikan terapi adalah 29,95 ( cemas berat). Adapun rata-rata kecemasan siswa sesudah diberikan terapi adalah 18,20 (cemas sedang).

Tabel 3 Analisis kecemasan siswa sebelum dan sesudah terapi relaksasi otot progresif

\begin{tabular}{|l|c|c|c|c|c|}
\hline \multicolumn{1}{|c|}{ Kecemasan } & Mean & SD & SE & T & p-value \\
\cline { 1 - 4 } Sebelum & 29,95 & 11,188 & 1,769 & 9,088 & 0,000 \\
\cline { 1 - 4 } Sesudah & 18,20 & 9,121 & 1,442 & & \\
& & & & & \\
\hline
\end{tabular}

Hasil analisis pada tabel 4 menunjukkan bahwa pada kelompok perlakuan terjadi penurunan nilai rata-rata beban keluarga sebelum dan sesudah terapi suportif sebesar 19,58. Penurunan rata-rata nilai beban pada kelompok perlakuan bermakna secara statistik, dimana nilai $p$-value $0,000 \leq \alpha$ $(0,05)$.

\section{Pembahasan}

Hasil penelitian menunjukkan bahwa terdapat penurunan kecemasan yang bermakna setelah mendapat terapi relaksasi otot progresif yakni kecemasan sebelum terapi 29,95 (cemas berat) menjadi 18,20 (cemas sedang). Hal ini juga didukung dengan hasil uji statistik didapatkan $p$ value $0,000 \leq \alpha(0,05)$.

Kecemasan yang terjadi di dalam kehidupan manusia sebagai dampak ketidakmampuan individu untuk beradaptasi terhadap situasi kehidupan dimana melibatkan sistem saraf otonom dalam tubuh. Sistem saraf otonom terdiri dari saraf simpatis dan sistem parasimpatis. Adapun kerja sistem saraf otonom ini secara tidak sadar akan berespon terhadap kecemasan yang dialami oleh individu. sistem saraf otonom akan menyebabkan terjadinya perubahan fisiologis seperti perubahan tanda-tanda vital yang merupakan tanda gejala dari kecemasan. Respon fisiologis fight or flight pada saat seseorang mengalami kejadian potensial berbahaya maka akan terjadi 
respon sistem saraf simpatis yang akan meningkatkan aktivasi kelenjar adrenal. Respon fightflight ini akan mengaktifkan sistem saraf untuk memacu aliran darah ke otot-otot skeletal, meningkatkan denyut jantung, napas menjadi cepat dan tekanan darah meningkat.

Terapi relaksasi otot progresif terbukti secara bermakna untuk menurukkan kecemasan terutama pada tanda fisiologis dari kecemasan. Terapi relaksasi otot progresif merupakan terapi relaksasi dengan gerakan mengencangkan dan melemaskan otot-otot pada bagian tubuh tertentu untuk memberikan perasaan relaksasi secara fisik. pada terapi ini, responden diarahkan untuk membedakan perasaan yang dialami saat kelompok otot dilemaskan dan dibandingkan ketika otot dalam kondisi tegang dan merasakan relaksasi pada saat otot dilemaskan. Pemberian terapi ini akan menghasilkan efek perasaan tenang dan mengurangi ketegangan. Hal ini sesuai pendapat Copstead dan Banasik (2009) yang mengatakan bahwa relaksasi otot akan mengaktivasi kerja sistem saraf pusat parasimpatis. Kerja sistem saraf parasimpatis berlawanan dengan sistem simpatis yang bekerja pada saat tubuh memerlukan banyak energi seperti dalam kondisi kecemasan sehingga berlawanan dengan ciri-ciri kecemasan.

Hal tersebut diatas selaras dengan penelitian Lee (2012) membuktikan bahwa terapi relaksasi otot progresif dapat menurunkan kecemasan pasien kanker ginekologi yang menjalani kemoterapi. Menurut Carver \& O’Malley (2015) bahwa terapi relaksasi otot progresif terbukti menurunkan kecemasan peserta didik yang sedang menjalani simulasi klinik. Selain itu terapi relaksasi juga menurunkan stres pada perawat yang bekerja di panti wreda (Mustikawati, 2015).

Berdasarkan self evaluasi menunjukan bahwa siswa yang menghadapi Ujian Nasional mengalami kecemasan menunjukkan penurunan belajar, sulit tidur, terkadang sulit berpikir hal lain dan hanya terfokus pada ujian. Hal ini sesuai dengan pendapat Suliswati (2010) mengatakan bahwa respon kognitif pada kecemasan dapat mempengaruhi kemampuan berpikir seseorang seperti ketidakmampuan memperhatikan, konsentrasi menurun, mudah lupa, menurunnya lapang persepsi dan bingung. Pemberian terapi relaksasi otot progresif memberikan dampak terhadap penurunan kecemasan terutama pada respon kognitif kecemasan, hal tersebut disebabkan efek relaksasi yang memberikan ketenangan dan kenyamanan pada klien. Hal ini sesuai pendapat Synder \& Lynquist (2010) mengatakan bahwa respon stres merupakan bagian dari jalur umpan 
balik yang tertutup antara otot-otot dan pikiran. Penilaian terhadap stressor mengakibatkan ketegangan otot yang mengirimkan stimulus ke otak dan membuat jalur umpan balik. Pemberian terapi otot progresif akan memberikan dampak relaksasi otot yang akan menghambat jalur tersebut dengan cara mengaktivasi kerja sistem saraf parasimpatis dan manipulasi hipotalamus melalui pemusatan pikiran untuk memperkuat sikap positif sehingga rangsangan stres terhadap hipotalamus menjadi minimal.

Hasil penelitian juga menunjukkan pada penurunan respon perilaku kecemasan setelah diberikan terapi relaksasi otot progresif, responden mengatakan tidak gelisah, tenang, muka rileks, napas normal. Menurut Prawitasari (2012) mengatakan bahwa terapi relaksasi otot progresif merupakan bagian dari terapi relaksasi yang dapat digunakan sebagai keterampilan koping yang aktif yang dapat mengajarkan individu kapan dan bagaimana menerapkan relaksasi dan kenyamanan dibawah kondisi yang menimbulkan kecemasan. Menurut Videbeck (2010) menyatakan bahwa apabila koping adaptif, maka individu tersebut dapat berada pada kecemasan yang sehat (kecemasan ringan), dan sebaliknya apabila koping individu maladaptif maka kecemasan individu membahayakan (kecemasan berat sampai panik). Selaras dengan penelitian Golfried dan Trier (1974, dalam Prawitasari, 2012) yang menunjukkan efektivitas latihan relaksasi progresif yang disajikan sebagai self control coping skill. Penelitian tersebut menunjukkan bahwa subyek yang diberi latihan relaksasi sebagai active coping skill secara signifikan menunjukkan penurunan kecemasan secara signifikan.

Selain respon perilaku, terapi relaksasi otot progresif juga berdampak pada penurunan respon emosi. Menurut Suliswati dkk (2010), mengatakan bahwa secara emosional klien yang mengalami kecemasan akan menunjukkan ekspresi bingung dan curiga berlebihan. Terapi relaksasi otot progresif memberikan efek perasaan rileks dan nyaman sehingga mempunyai dampak terhadap emosional klien. dengan demikian, klien akan mampu mengendalikan penguasaan diri berupa kondisi sabar dalam menghadapi Ujian Nasional dan kepercayaan diri meningkat. Hal ini sesuai pendapat Kwekkboom \& Gretarsdottir (2009) yang menyatakan bahwa terapi relaksasi otot progresif yang memberikan efek relaksasi adalah kondisi bebas secara relatif dari kecemasan dan ketegangan otot skeletal yang dimanifestasikan dengan ketegangan, 
kedamaian, dan perasaan ringan. Dengan adanya perasaan tenang dan damai, maka akan mempengaruhi emosional seseorang menjadi lebih baik.

\section{Kesimpulan}

a. Kecemasan siswa sebelum diberikan terapi relaksasi otot progresif rata-rata adalah 29,95,

b. Kecemasan siswa sesudah diberikan terapi relaksasi otot progresif rata-rata adalah 18,20.

c. Terdapat perbedaan nilai kecemasan siswa Ujian Nasional sebelum dan sesudah diberikan terapi relaksasi otot progresif dengan nilai $p$-value $=0,000$.

\section{Saran}

1. Perlu diadakan penelitian kombinasi antara terapi relaksasi otot progresif dengan terapi lainnya seperti terapi kognitif, thought stopping pada siswa yang lebih luas dengan metode random sampling.

2. Dapat dilakukan penelitian tentang faktor-faktor yang mempengaruhi kecemasan siswa dalam menghadapi Ujian Nasional

3. Perlu dilakukan penelitian lanjutan dengan metode kualitatif untuk mengetahui keefektifan terapi relaksasi otot progresif. 


\section{Daftar Pustaka}

Carver, M.L., \& O’Malley. (2015). Progressive muscle relaxation to decrease anxiety in clinical simulations. Teaching and Learning in Nursing Journal, 10 (2), 57-62

Copstead, L. C \&Banasik, J. L. (2009). Pathofisiology (2 nd ed). Philadelphia: W. B. Saunders Company

Hawari D. (2012). Manajemen Stres, Cemas dan Adaptasi. Jakarta: Salemba Medika

Lee, J. E. (2012). Monochord sounds and progressive muscle relaxation reduce anxiety and improve relaxation during chemotherapy. A pilot EEG study: Complementary Therapies in Medicine.

Mustikasari. I. F. (2015). Efek terapi relaksasi otot progresif dalam menurunkan tingkat stress kerja pada perawat panti wreda Elim di Semarang. Tesis. Magister Fakultas Psikologi Universitas Katolik Soegijapranata Semarang

Prawitasari. J.E. (2012). Psikologi Terapan Melintas Batas Disiplin Ilmu. Jakarta: Penerbit Erlangga.

Stuart, G. W \& Laraia, M. T (2013). Principles and practice of psychiatric nursing. St Louis: Mosby

Suliswati. (2010). Konsep Dasar Keperawatan Jiwa. Jakarta : EGC.

Synder, M \& Lyndquist, R. (2010). Complementary alternative therapies in nursing (4 th ed). New York: Springer Publishing Company

Videbeck, S. L. (2010). Buku Ajar Keperawatan Jiwa. Jakarta: EGC

Wahyudin, D. (2011). Pengantar Pendidikan. Jakarta: Bumi Aksara 